\section{COLONIALISM AND \\ PATRIARCHY: \\ INTERWOVEN POWERS \\ IN BURMESE DAYS' \\ INTERWOVEN PLOTS}

\section{Sutida Wimuttikosol ${ }^{1}$}

\begin{abstract}
Burmese Days, one of George Orwell's less well-known works, is often regarded as his personal testimony about his traumatic experiences in Burma. Since it portrays the life of a white man living in the colony, the theme of colonialism has been quite exhaustively explored. In contrast, gender issues in the novel have been left almost untouched. This article proposes that Burmese Days does not have only a single plot. Another plot, the patriarchal plot, develops alongside the colonial plot, although more subtly. Through these parallel plots, the interrelation between colonialism and patriarchy, together with the cooperation of the subjects under their domination, is revealed. Besides offering the reader another perspective on Burmese Days, this analysis aims to cast some light on the nature of power. Because the two powers in the novel work interdependently, it can be said that a particular power does not have a "center" within itself. It can be exercised and maintained through other kinds of power, which means many participants are included. Therefore, it cannot be straightforwardly dismantled. Instead, the whole oppressive system in
\end{abstract}

\footnotetext{
${ }^{1}$ Lecturer, Department of English Language and Literature, Faculty of Liberal Arts, Thammasat University, Bangkok.
}

which diversified elements interplay must be questioned.

\section{Introduction}

Several studies of George Orwell's Burmese Days (1934) see it as the author's personal testimony about the British empire. Critical responses to the book are mostly concerned with the issue of colonialism, debating Orwell's standpoint and the book's position within the antiimperial context. While John Newsinger (1999: 10) insists that Burmese Days is "a savage indictment of British Imperialism," and that Orwell is "a committed supporter of the cause of Indian Independence," Shamsul Islam (1979: 81) comments that, for Orwell, "the Raj is not so bad after all." On the other hand, Holderness and his colleagues (1998: 4) consider the novel "an ambivalent text" which produces "ambivalent readings," arguing that Orwell's position as an agent of the empire is contradictory to his work, while he attempts to demystify the imperial myth. These debates certainly cast different lights on the book in relation to colonialism. However, what has been overlooked is the role of patriarchy as another set of power relations that both supports and is supported by colonialism and thus plays an important part in the novel. As Stoler (1989: 635) has argued, colonial authority was premised on the interstices of boundaries of racial and gender identities by means of which the identity and position of power of a colonial subject was constructed. This article proposes to examine the interrelationship between patriarchy and colonialism and, in particular, to examine how it supports colonial power. 


\section{Interwoven plots: the interdependence of colonialism and patriarchy}

Burmese Days narrates a moment in the waning days of the Empire when the colonial authority in Kyauktada is compelled to adopt a new policy to recruit a native into the European club as part of the strategy to maintain colonial power and prestige. Along with this challenge to colonial rule, the romantic relationship between Flory, an unpopular colonial agent, and Elizabeth, a young English woman fresh from England looking for a suitable husband and a secure future, begins and ends. Contrary to Ingle's suggestion that the recruitment functions as the novel's main plot and the marriage as its subplot (Ingle 1998), it can be argued that both plots are interrelated, each equally important and interacting with each other throughout the novel. To illustrate, Flory's desire to get a wife and construct his own home, and his subsequent and tragic failure to do so, results from his inability to fit into the colonial community. This failure is reflected in his political decision (or indecision) regarding the recruitment of the native. Likewise, Elizabeth's choice of husband, and her admission into the colonial hierarchy, depends on the man's political attitude and colonial position. Through their interaction, these two plots make visible the concomitant powers, colonialism and patriarchy, ${ }^{2}$ that potently

\footnotetext{
${ }^{2}$ Class issues are also evident, and it can be argued that both imperial and patriarchal powers in the novel manifest themselves in the form of social class differences. However, here I would like to make a clear distinction between two kinds of power and discourses, and examine how they are interwoven through the narrative.
}

operate together through their subjects. Despite their seemingly unrelated fields, they support each other and powerfully govern their subjects in both public and private spheres. Additionally, the characters show how people, complying with the rules of their subject positions, cooperate in supporting the mechanisms of power over them. These two key ideasthe interrelation between colonialism and patriarchy and the cooperation of the subjects-make the power less tangible, more elusive and hence more pervasive.

Even though the two plots are intertwined, here they are discussed separately so as to emphasize first their apparent unrelatedness and then to demonstrate their subtle links. By the "plot" here, I mean both the structure of the narrative and a sense of unwitting conspiracy between the characters in supporting colonialism and patriarchy at the same time.

\section{The colonial plot: the institutionalization of the club}

Inside, the Club was a teak-walled place smelling of earth-oil, and consisting of only four rooms, one of which contained a forlorn library of five hundred mildewed novels, and another an old and mangy billiard-table - this, however, seldom used, for during most of the year hordes of flying beetles came buzzing round the lamps and littered themselves over the cloth. (Orwell 1989: 17)

The excerpt above vividly portrays the irony of the club as the symbolic center of the empire. Supposedly signifying imperial "civilization," the club ironically reveals the empire in a state of decline. 
The library, a symbol of knowledge and intellectuality, is "forlorn" while the recreational facilities-such as the billiard-table-rarely have an opportunity to fulfill their duty. Ironically, the state of the club is affected by the local environment and reflects the pitiful condition of the imperial agents within the colony. The hot and humid weather and the local insect life prevent them from doing any activity believed to be the sole privilege and mark of the sophisticated taste of members of a civilized race, and thus expose their superficiality. The "flying beetles" make it impossible to enjoy the billiards, while the mildew that creeps up on the unused books highlights the British officers' indifference to knowledge and arts. As the novel gradually reveals, the club is a microcosm of the empire itself, showing off its superiority and disclosing its own problems at the same time.

Despite the decline of the club, its ideological and political significance cannot be overlooked. As the only refuge for white officials stationed in the remote outpost of Kyauktada, the club is exclusively reserved for colonial masters and is thus an embodiment of colonial solidarity. Even though the billiards room fails to act as a site of entertainment, it is still the site where colonial togetherness is displayed and reaffirmed, for it is where the colonizers hang together and feel the air of Britishness. Accordingly, the club retains its significance as a symbolic space for colonial privilege and power, creating an invisible barrier between insiders and outsiders, masters and servants, the self and the other. Located in the centre of the town, the club is also the centre of the natives' attention, and thus, granted the latter's indoctrinated sense of inferiority, reinforces the club's position as the undisputed manifestation of colonial superiority that transcends even Nirvana, the supreme achievement of being according to Buddhist belief:

When one looked at the Club-a
dumpy one-storey wooden
building-one looked at the real
centre of the town. In any town in
India the European Club is the
spiritual citadel, the real seat of
the British power, the Nirvana for
which native officials and
millionaires pine in vain. It was
doubly so in this case, for it was
the proud boast of Kyauktada
Club that, almost alone of Clubs in
Burma, it had never admitted an
Oriental to membership. (Orwell
1989: 14)

The analogy of the Club with Nirvana suggests its power to transform the natives. Just as Nirvana is believed to transform a human being into a state of spiritual non-existence, freed from any burden in the secular world, the club is perceived to endow upon the natives a new status that rids them of racial inferiority. Of course, the words "in vain" imply impossibility; no native can ever be granted this privilege, no matter how they try. This condition underlines the exclusiveness and power of the club and makes it all the more tantalizing for the natives.

The Club's function as a symbolic site of colonial power and the allure of its prestige in the eyes of natives then make the recruitment of the natives doubly significant. For the British, recruitment is a necessary strategy to maintain their power within the colony. For the natives, the policy offers an opportunity to partake 
of the power and privilege of Empire. The importance of the strategy is all the more urgent, given the challenge to the Empire as a consequence of the Indian Mutiny and the spread of nationalism. According to Gilmour (2006: 17), the Mutiny not only occasioned in the British colonial authority a fear of the natives and a realization of the latter's substantial power to challenge colonial rule; it also compelled them to reconceptualize the relationship between the colonizer and the colonized: "rewarding loyalty and conciliating the aggrieved" (Gilmour 2006: 17) was necessary in order to maintain colonial rule and, by seemingly placating the grievances and the demands of the colonized, to contain them. ${ }^{3}$

The conversations among the European characters in the novel reveal that, under the impact of the changing circumstances, the small white community is under threat;

We seem to have no authority over the natives nowadays, with all these dreadful Reforms, and the insolence they learn from the newspapers. (Orwell 1989: 26)

...I am afraid there is no doubt that the democratic spirit is creeping in, even here. (Orwell 1989: 27)

Ironically, the law and education brought by the colonizers contributed to the cultivation and spread of "the democratic spirit," and motivated the Burmese people towards a recognition of and demand for

\footnotetext{
${ }^{3}$ The "indianization" of the colonial administration from 1886-1925 (Blunt 1999: 422) also evidenced negotiations between the colonizer and the colonized in the face of Indian nationalism.
}

their own rights. Even Kyauktada, an outpost of the empire, is no exception. For the British government, the fact that the club in Kyauktada is the last non-native club in Burma is nothing to boast about; it is simply evidence of the colonial pride and prejudice that will eventually destroy their justification to rule. That is why the new policy to receive a native member is launched, even though it is against the will of the British members. It is an effective method to simultaneously reaffirm colonial rule and placate the natives.

Not unexpectedly, the policy is not gladly received by the European members whose sense of exclusiveness and superiority is threatened. Ellis, an outspoken racist, proclaims that the white members must "hang together" to defend the club against the invasion of the "pot-bellied niggers":

That would be a treat, wouldn't it? Little pot-bellied niggers breathing garlic in your face over the bridgetable. Christ, to think of it! We've got to hang together and put our foot down on this at once... I'll die in the ditch before I'll see a nigger in here. (Orwell 1989: 20)

Security becomes so important that even their personal rivalry and dislikes are put aside, prompting vituperative reaffirmations of their legitimacy and ability to rule. Nonetheless, the constructed images of the colonized as dangerous savages betray the colonizers' insecurity and fear. Any intrusion into the exclusive area of the club is felt to be intolerable, just as the apparent acceptance of social equality between the races destabilizes the colonial and racial hierarchy. This ambivalence of anxiety and superiority underlines their compulsion to strictly maintain hierarchical differences of race by being 
exclusively "white" and united, so that the distance between the colonizers and the colonized is kept.

By contrast, for the natives, the recruitment policy enhances the allure of colonial power. Admission to the Club, for them, means less a step towards powersharing reform and equality, but more an opportunity to boost their own personal prestige and power. U Po Kyin, the ambitious officer who has already more than enough power and money, sees that every success in his life is nothing when compared to admission to the club, the place where he can share the superiority of the colonizer. Even Ma Kin, his religious wife who at first disagrees with his maneuvering, is unable to resist the temptation when he reveals that his final objective is to be accepted into the club:

And not without reason, for all the achievements of U Po Kyin's life were as nothing beside this. It is a real triumph-it would be doubly so in Kyauktada-for an official of the lower ranks to worm his way into the European Club. The European Club, that remote, mysterious temple, that holy of holies far harder of entry than Nirvana! (Orwell 1989: 147-148, my italics)

Similarly, the Indian doctor Veraswami, because of his insecurity as an Indian among the Burmese and an easy target of racial jealousy, believes that membership to the Club as a visible sign of equality with the Europeans can protect him;

If I were elected to the Club! Ah, indeed, yes! The Club! It is a fortress impregnable. Once there, and no one would listen to these tales about me any more than if it were about you [Flory], or $\mathrm{Mr}$ Macgregor, or any other European gentleman. (Orwell 1989: 154, my italics)

In this colonial plot, then, both the Europeans and the natives play important roles in strengthening colonial power. Together, the Europeans' bitter resistance to the policy and the natives' endeavor to get into the club emphasize the function of the club as the key to colonial prestige. Even U Po Kyin, who, unbeknown to the British, undermines colonial authority through his schemes and corruption, is covetous enough of colonial prestige and power to submit to it. Through the process of election, the Club becomes institutionalized. Ironically, even though recruitment enables the colonial authority to regain stability, it does not of course ensure the power of colonial rule. U Po Kyin cunningly manipulates the colonial discourses by laboriously displaying his loyalty and Veraswami's disloyalty through a fake rebellion. What he truly desires is the personal power he gains by being seen to support the empire, not the empire itself. The white officers, of course, are not aware of this surreptitious design. Their underestimation of the native's cunning partly leads to the demise of the empire.

Although the recruitment of a native member holds considerable significance, it plays only a partial role in supporting colonial power. The club's power, albeit significant and visible, operates only in the public sphere. If, as Stoler has argued, colonial power operates through the interstices of gender and race, it means that colonial power extends also to the private sphere. In this light, the colonial home becomes just as important, if not 
more, in the operation of colonial authority. The significance of the space of "home" in the novel will now be examined.

\section{The patriarchal plot: the construction of the colonial family}

In this patriarchal plot, Flory and Elizabeth, the major characters who are obsessed by the desire to marry, exemplify how both men and women are dominated by patriarchal discourse and take part in supporting the power over them. While Flory needs a wife to construct a home where he can be a master, Elizabeth needs a husband who can protect her from such a hostile world for a single woman and, in particular, who can fulfill her dream of a secure, comfortable home. Their motivation cannot be seen as purely personal. Through the examination of Flory's idea of home and Elizabeth's role as a wife, the link between their personal aspirations and their political function as imperial agents is discernible.

With a shameful birthmark that seems to advertize his disreputable existence, Flory is alienated from the other Europeans due to his sympathy for the natives. He retreats from society and always suffers from "homesickness." However, Flory's thought of Elizabeth reveals that his "home" is not a geographical space like England, his motherland, but is an ideological space where he can construct a husband-and-wife relationship:

...it seemed to him that his house, his flowers, his servants, all the life that so short a time ago had been drenched in ennui and homesickness, were somehow made new, significant, beautiful inexhaustibly. What fun it could all be, if only you had someone to share it with you! (Orwell 1989: 157)

It appears here that Flory's homesickness is a crisis of identity. As a loner unable to get along with other white folks, he cannot identify himself with his surroundings and can comprehend himself only very vaguely. Yearning for someone to "share" his life with, Flory actually wants someone to help him construct his self-image. What he associates with his life are "his house, his flowers, his servants"-all his possessions in the domestic sphere. These objects imply Flory's expectation of Elizabeth's function: he wants her to witness his authority in the familial space. In other words, he wants her to play the role of a wife so that he can be a husband and define himself as a "real" man. Thus, after meeting Elizabeth, Flory tries to give up his dissipated behavior as a bachelor and to transform himself into a gentleman by showing manly qualities such as bravery in many incidents to prove his suitability and ability as a husband. The discourse of patriarchy is central to how Flory defines himself and how he hopes to win colonial acceptance.

Home is also what Elizabeth, a young English lady, craves. As a woman, she is in exile both in England, her homeland, and in British Burma. Insulted by her employer in England, she is abused by her uncle in Burma. Ellis's abusive speech about her further reveals the contempt felt by colonial agents for white women who 'come out' to the colony:

As if it wasn't well known! When a girl's failed everywhere else she tries India, where every man's pining for the sight of a white woman. The Indian marriage- 
market, they call it. Meat market it ought to be. Shiploads of 'em coming out every year like carcasses of frozen mutton, to be pawed over by nasty bachelors like you. Cold storage. Juicy joints straight from the ice. (Orwell 1989: 113)

Elizabeth's situation demonstrates how patriarchal society compels a woman to subject herself to men through marriage. Without a "home," she is exploited by men, either verbally or physically. An unmarried woman's status could be worse than that of a prostitute. Having no authority to protect herself, she has only one way to escape from this status as public property and gain protection: to become the private property of a man in his "home." In Elizabeth's case, her need to marry is further exacerbated by her dream of an affluent, elegant lifestyle and a social status to which her education exposed her but which, through reason of class and poverty, is out of her reach. "Coming out" to the colony is one way for her to find the "right" husband who can realize her desire.

Marriage in the colony is not a personal matter but a political action. The colonial family is an essential part of the colonial mechanisms of power. As McClintock points out, the western patriarchal ideology fully participates in colonialism by reinforcing the racialized hierarchy of the colonial relations of power:

Because the subordination of woman to man and child to adult was deemed a natural fact, hierarchies within the nation could be depicted in familial terms to guarantee social difference as a category of nature. The metaphoric depiction of social hierarchy as natural and familial-the "national family," the global "family of nations," the colony as a "family of black children ruled over by a white father"- - depended in this way on the prior naturalizing of the social subordination of women and children within the domestic sphere. (McClintock 1998: 91)

Incorporated into colonial discourse, the family is the model according to which the global relationship is constructed. The structure of familial relations where men have "rightful" authority becomes an analogy for the relationship between the colonizer and the natives. The "family man" as "protector of the family" becomes the ideal image of the colonizer whose rule over the natives is justified in the name of protection. Accordingly, both white men and women have dual roles within the colonial context. As head of the family, a white man is also father of the natives; as wife, a white woman is their mother.

The function of "home" as a microcosm of colonial authority became important as a result of important changes in colonial strategy and discourse. According to Stoler, marriage and white women were first prohibited in the colony, while concubinage with native women was encouraged:

Native women (like European women in a later period) were to keep men physically and psychologically fit for work, marginally content, not distracting or urging them out of line, imposing neither the time consuming nor financial responsibilities that European 
family life was thought to demand. (Stoler 1989: 637)

Compared with concubinage, the western family was seen as an obstacle to effective colonial operations. Ironically, miscegenation became a problem because it jeopardized European cultural identity by blurring the boundaries of racial difference between the white colonizer and the native. Through the presence of white women and their feminine attributes, domestic and familial values were deemed necessary for the retention of racial purity and prestige. A colonial home thus became an imperial space within which imperial values and power could be reimposed.

The function of home and the role of women were redefined as a result of the Mutiny. According to Blunt, during the Mutiny the British fear of native defiance was focused on the vulnerability of the British female body and the British home represented as objects of native violence. They were now to be reconstructed such that imperial power was embodied in the images of women and their relationship with natives (Blunt 1999: 427). Establishing and maintaining imperial power relations was now seen as an important duty of British women, and the display of female dignity and prestige in the domestic sphere was equal in importance to imperial rule. As Blunt points out, the increase in household guides giving advice on the management of servants as part of the necessary domestic skills rose sharply after the Mutiny, according to which the exercise of "parental care, discipline and wisdom" (Blunt 1999: 430) by the memsahib in their surveillance of native servants was as important as the colonial man's masculine virtues of adventure, courage and disciplinary firmness. This change of role also meant a more prominent social status for colonial women: they were not just home-makers but also colonial agents, crucial to the successful operations of imperial power.

In light of the changing significance of the discourse of colonial domesticity, the full urgency and meaning of Flory's and Elizabeth's desire to marry can be understood. Flory's imaginary "home" in Kyauktada sufficiently reflects the imperial model of the white man's "family." It is not just a private world for him and his wife, but a small community in the native space where he is the master:

Like a hallucination, painfully clear, he saw again their home as he had imagined it; he saw their garden, and Elizabeth feeding Nero ["the tame fighting cock"] and the pigeons on the drive by the sulphur-yellow phloxes that grew as high as her shoulder; and the drawing-room, with the water colours on the walls, and the balsams in the china bowl mirrored by the table, and the book-shelves, and the black piano. The impossible, mythical pianosymbol of everything that that futile accident has wrecked! (Orwell 1989: 290)

Flory not only hopes to be the master in the family, but also sees himself as the master of the native space. He can be both "protector," building an ideal shelter for his wife, and "ruler" making his household an ideal colony. In his house, the domestic sphere of the "dangerous" colonial space, the wife is protected from the danger of both white and native men and becomes a queen. Besides providing security, the house makes her feel "at home." An 
atmosphere of British comfort and civilization can be constructed by furniture, especially the piano, which Flory mentions earlier as the symbol of "civilized and settled life" (Orwell 1989: 258). Moreover, in his imagination, the wild, native, natural surroundings are rearranged and changed into a wellgroomed Western garden, so that the couple can feel comfortable living within. Flory's imaginary home is also the colonizer's ideal space in which he harmoniously rules and protects the natives. His wife's activity signifies the white man's burden. She helps her husband take care of the tamed animals, "Nero" and the pigeons, symbolizing the natives in the colonizer's domestic sphere that come to the "kind" masters who provide them with food and shelter. Marriage, therefore, is meant to help Flory specifically create his self-image not just as a man, but as a white man, whose family supplies an ideal "home" where his subordinates, both in racial and sexual terms, feel satisfied with their security and limited freedom.

It is important that Flory's imaginary schema of colonial domesticity is both accepted and resented in the ambivalent power relations of the lived colonial experience. As an embodiment of colonial power in the domestic sphere, Elizabeth's imagined presence becomes an object of fear for Ko S'la, Flory's male domestic servant:

I shall not leave, for I have been his servant fifteen years. But I know what is in store for us when that woman comes. She will shout at us because of spots of dust on the furniture, and wake us up to bring cups of tea in the afternoon when we are asleep, and come poking into the cookhouse at all hours and complain over dirty saucepans and cockroaches in the flour bin. It is my belief that these women lie awake at nights thinking of new ways to torment their servants. (Orwell 1989: 118)

Elizabeth's imagined domestic skills would restore the colonial order and authority that had been usurped through Flory's dissipated life and uncertain colonial identity. It is interesting to note that Ko S'la's reversal of the colonial relations depends precisely on accepting the symbiotic relationship between the discourses of patriarchy and colonialism. Using marital status as a criterion of manliness and superiority, Ko S'la sees Flory as "a boy":

In Ko S'la's eyes Flory, because a bachelor, was a boy still, whereas Ko S'la had married, begotten five children, married again and become one of the obscure martyrs of bigamy. Like all bachelors' servants, Ko S'la was lazy and dirty, and yet he was devoted to Flory. . . . He was inclined to pity Flory, partly because he thought him childish and easily deceived, and partly because of the birthmark, which he considered a dreadful thing. (Orwell 1989: 48)

The stereotypical roles of the master and the slave are reversed. Instead of being a patriarch, Flory becomes the child of a native father. His shameful birthmark emphasizes his pitiful condition even in the eyes of the slave. Accordingly, Ko S'la assumes that it is his duty to take care of this white child, and through the identification with Flory, he finds himself 
a superior native. He does not allow anyone in the household to serve Flory at the table, and even feels "jealous of Ma Hla May's influence in the house" (Orwell 1989: 49). Flory's home, thus, is the territory where Ko S'la can exercise his power and construct his identity. Flory's marriage to Elizabeth would, of course, destroy both and reinstall the colonial hierarchy of power in which the native servants are put back in their place.

The idealized space of colonial domesticity is, of course, restricted to white people only. Elizabeth's rejection of Flory, once his relationship with Ma Hla May is exposed, underlines the racial repulsion and fear intrinsic to colonial power relations. Flory's concubinage with a native woman is not just a personal aberration, but a threat to the racialized colonial hierarchy. Unlike other submissive concubines, Ma Hla May forcefully demands power, positioning herself in the place of a "bokadaw," a white man's wife:

Look at me, you white men, and you women too, look at me! Look how he has ruined me! Look at these rags I am wearing! And he sitting there, the liar, the coward, pretending not to see me! $\mathrm{He}$ would let me starve at his gate like a pariah dog. (Orwell 1989: 285 , my italics)

Seeing herself as a member of a Western family, she demands sympathy for Flory's cowardly abnegation of responsibility. Her transgression is clearly what the colonizers fear. She considers herself equal to white women and manipulates the ideology of the family to ask for financial support, blurring the boundary between the ruler and the ruled. As for Flory, his inability to keep his mistress in her "proper" position and reply to her charge simply exposes and reaffirms his "unmanliness," and worse still, damages his racial superiority. His loss of Elizabeth is, of course, no personal failure but closely linked to his loss of colonial identity and power. The original motivation to destroy Flory for his support of Veraswami's attempt to gain admission to the club might be highly political; yet, the effective method to get rid of him is the denunciation of his personal life. The public sphere and the domestic, personal sphere are inevitably intertwined in the colonial power relations.

How does Elizabeth herself fit into this schema of colonial domesticity? As Blunt has argued, through their prescribed domestic role that reproduced imperial power, colonial women were "'incorporated wives' in the imperial aristocracy, gaining their status through the occupation and position of their husbands" (Blunt 1999: 423). In Elizabeth's case, her need for a secure home is compounded by her personal ambition for a social status that will not only give her the recognition that she craves but also the lifestyle of affluence and power of her school friends. Her relationship with Flory denies her this opportunity to gain admission to the colonial hierarchy on which the success of her ambition depends. Indeed, it is not only her apparent sophistication and elegance, but also her repulsion for anything native as "beastly" as well as her instinctive attraction to power, manifested in the pleasure she takes in hunting, that seems to equip her as a perfect memsahib. If the British empire barely survives the machinations of the wily U Po Kyin, it lives on unchallenged in her household, where the Burmese servants "live in 
terror" (Orwell 1989: 272) under her supreme rule.

\section{The effects of the two powers upon their subjects: empowerment and enslavement}

Due to colonial obligation, Elizabeth, who is actually in a desperate situation, has the authority to choose a husband, which might be impossible outside the colonial context. Moreover, even though she is not allowed to take part in such public matters as the election of the native, she plays a significant role in supporting colonial power. Thus, to a considerable extent, colonialism empowers white women like Elizabeth. Her female roles and characteristics become essential to the British empire. However, this empowerment can also be seen as enslavement. Elizabeth gains power, not by questioning or undermining the power over her, but by embracing the received gender ideology and using it to oppress the racial others. In other words, although colonialism seems beneficial to a white woman, it does not emancipate her from patriarchal domination; instead, it reproduces gender ideology and makes the woman confine herself within the domestic sphere on behalf of the empire. Illusory as it is, the colonial discourse, which is based heavily on patriarchal ideology, effectively prevents women from fighting for gender equality.

When looking at the colonial plot, we can see that U Po Kyin, like Elizabeth, also acknowledges his own "natural" inferiority. Being a native, he is contented with the limited power given by the colonizer as long as it is advantageous to him. Despite his cunning, he does not try to fight against the dominating power but submits to it in order to share colonial prestige. Even though he is capable of organizing a rebellion, he chooses to do it simply to display his allegiance to the British empire, not to defy its power. Colonial discourse systematically dominates him. First, it convinces him of his inferiority and the colonizer's superiority. Then, through the recruitment of the native, it lures him with the possibility of sharing colonial power by means of submission. Through identification with the colonizer, U Po Kyin actually confines himself under the dominating power with consent. To put it another way, his empowerment is at the same time his enslavement.

It is also remarkable that both Elizabeth and Kyin's processes of empowerment are achieved through the denunciation of Flory. Although they never meet each other, they cooperate in getting rid of this "improper" white man in relation to whom they are hierarchically inferior in terms of gender and race respectively. This proves that even a white man is dominated by colonialism and patriarchy. His position is not intrinsically secure; he has to comply with the colonial and patriarchal rules to achieve his superior status. Just like his racial and sexual subordinates, he is compelled to play the "proper" roles of the master. Otherwise, he is vulnerable to being destroyed even by subordinates, who take a considerable part in maintaining the powers over them both by submitting to them and by eliminating improper "others." Thus, we can say that all the subjects under colonial and patriarchal power, regardless of their hierarchical positions, are both empowered and enslaved by the two forces, although in different ways and to different degrees.

Burmese Days, then, is not merely a novel about Orwell's bitter critique of the British 
Empire's system of oppression or about its decline. Through its revelation of the interrelationship between patriarchy and colonialism, the novel exposes the elaborate and subtle operation of colonial power in its domination of its subjects not through coercion but cooperation. Not only white men, but also women and even the colonized are its effective agents. Arguably, the web of discursive control, such as the novel reveals, extends beyond that of colonialism and patriarchy into the most banal practices of everyday life, perhaps even in instances of resistance to the power of discourse itself.

\section{References}

Blunt, Alison. 1999. Imperial Geographies of Home: British Domesticity in India 1886-1925. Transactions of the Institute of British Geographers, New Series 24.4: 421-440.

Gilmour, David. 2006. The Ruling Caste: Imperial Lives in the Victorian Raj. New York: Farrar, Straus and Giroux.

Holderness, Graham, Bryan Loughrey and Nahem Yousaf. (eds.). 1998. George Orwell. Basingstoke: Macmillan Press.

Ingle, Stephen. 1998. The AntiImperialism of George Orwell. In George Orwell, edited by Graham Holderness, Bryan Loughrey and Nahem Yousaf, pp. 228-246. Basingstoke: Macmillan Press.

Islam, Shamsul. 1979. Chronicles of the Raj: A Study of Literary Reaction to the Imperial Idea towards the End of the Raj. London: Macmillan Press.

McClintock, Anne. 1998. No Longer in a Future Heaven: Gender, Race and
Nationalism. Dangerous Liaisons: Gender, Nation, and Postcolonial Perspectives, edited by Anne McClintock, Aamir Mufti, and Ella Shohat, pp. 89-112. Minneapolis: University of Minnesota Press.

Newsinger, John. 1999. Orwell's Politics. Basingstoke: Macmillan Press.

Orwell, George. 1989. Burmese Days. London: Penguin.

Stoler, Ann L. 1989. Making Empire Respectable: The Politics of Race and Sexual Morality in 20th-century Colonial Cultures. American Ethnologist 16.4: 634-660. 